\title{
Markedly raised synovial fluid leucocyte counts not associated with infectious arthritis in children
}

\author{
ANDREW R. BALDASSARE, FRANK CHANG, AND \\ JACK ZUCKNER
}

From the Division of Rheumatology, Department of Internal Medicine, St. Louis University School of Medicine, St. Louis, Missouri, USA

SUMMARY Synovial fluid leucocyte counts greater than 50000 cells $/ \mathrm{mm}^{3}\left(50 \times 10^{9} / \mathrm{l}\right)$ are usually ir associated with infectious arthritis. Six children, 3 of whom meet the criteria for juvenile rheumatoid arthritis (JRA), are described with synovial fluid white blood cell counts greater than 88000 cells/ $\mathrm{mm}^{3}\left(88 \times 10^{9} / 1\right)$. Two had synovial fluid leucocyte counts greater than $100000 \mathrm{cells} / \mathrm{mm}^{3}(100 \times$ $\left.10^{9} / 1\right)$. The diagnosis of infectious arthritis was unlikely in these 6 children since the synovial fluid smears and cultures for infectious agents were negative and their histories atypical for infection. While in most instances such markedly raised synovial fluid leucocyte counts indicate infection, this finding is not diagnostic of septic arthritis.

Synovial fluid leucocyte (WBC) counts can often be helpful in differentiating the many arthritides. Counts of less than 2000 cells $/ \mathrm{mm}^{3}\left(2 \times 10^{9} / \mathrm{l}\right)$ are generally associated with conditions like traumatic arthritis, osteoarthritis, and osteochondritis dissecans (Hollander and McCarthy, 1972). Values between 2000 50000 cells $/ \mathrm{mm}^{3}\left(2-50 \times 10^{9} / 1\right)$ are commonly found in rheumatoid arthritis, other connective tissue diseases, and gout. Synovial fluid leucocyte counts below 50000 cells $/ \mathrm{mm}^{3}\left(50 \times 10^{9} / 1\right)$ are occasionally present in infectious arthritis, but typically the values in these cases are greatly raised. Thus, WBC counts greater than $50000-60000$ cells $/ \mathrm{mm}^{3}$ $\left(50-60 \times 10^{9} / 1\right)$ are, with rare exceptions, due to infection. Synovial fluid WBC counts greater than 80000 cells $/ \mathrm{mm}^{3}\left(8 \times 10^{9} / \mathrm{l}\right)$ have been observed in 6 children who lacked evidence for infection. Their case histories are presented here.

\section{Case reports}

C A S E 1

A 31-year-old white male was admitted to Cardinal Glennon Memorial Hospital (CGMH) with a 5-day history of low grade fever. Two days before admission, the child began to walk with a slight limp,

Accepted for publication September 27, 1977

Correspondence to Dr Andrew R. Baldassare, Division of Rheumatology, St. Louis University Hospital, 1325 South Grand Boulevard, St. Louis, Missouri 63104, USA. and swelling was noted in the right knee. He was seen by his private physician and given an intramuscular injection of penicillin. The swelling in the right knee continued and the child was hospitalised. The remainder of the history was unremarkable.

On physical examination, the temperature was $104^{\circ} \mathrm{F}\left(40^{\circ} \mathrm{C}\right)$ pulse $110 / \mathrm{min}$ and blood pressure $100 / 70 \mathrm{mmHg}(13 \cdot 3 / 9 \cdot 3 \mathrm{kPa})$. He appeared irritable. There was 2 plus heat, 2 plus tenderness, and a moderate effusion in the right knee. Flexion of the knee was moderately limited and was associated with pain. The remainder of the physical examination including a slit-lamp ophthalmological examination was unremarkable.

Laboratory evaluation revealed haemoglobin of $10.0 \mathrm{~g} / 100 \mathrm{ml}(\mathrm{g} / \mathrm{dl})$, haematocrit of $31 \%$, and WBC count of 11000 cells $/ \mathrm{mm}^{3}\left(11 \times 10^{9} / 1\right)$ with $6 \%$ 응 stabs, $67 \%$ polys, and $27 \%$ lymphocytes (lymphs). The erythrocyte sedimentation rate (ESR) was $36 \%$ $\mathrm{mm} / \mathrm{h}$. Rheumatoid factor (RF) and fluorescent $N$ antinuclear antibody (FANA) were not present. Lupus erythematous preps (LE cells) were negative. Radiology of the right knee was normal. An electrocardiogram (ECG) showed no abnormalities.

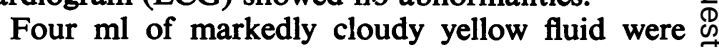
aspirated from the right knee. The synovial fluid WBC count was 93000 cells $/ \mathrm{mm}^{3}\left(93 \times 10^{9} / 1\right)$ with $96 \%$ polys and $4 \%$ lymphs. Synovial fluid glucose $\mathbb{D}$ was $62 \mathrm{mg} / 100 \mathrm{ml}(3.44 \mathrm{mmol} / \mathrm{l})$ with a simultaneous blood level of $170 \mathrm{mg} / 100 \mathrm{ml}(9.44 \mathrm{mmol} / \mathrm{l})$. Gram stain of the synovial fluid was negative. Blood 
and synovial fluid cultures for pyogenic bacteria, fungi, and mycobacteria were negative.

Oxacillin, $100 \mathrm{mg} / \mathrm{kg} / \mathrm{day}$, was administered intravenously because of suspected infection. After 2 weeks of intravenous antibiotic therapy, the right knee still had moderate swelling and tenderness. Subsequent synovial fluid WBC counts varied between $20000-50000$ cells $/ \mathrm{mm}^{3}\left(20-50 \times 10^{9} / 1\right)$. On the 15th day in hospital, synovial tissue was obtained by closed biopsy of the right knee using a Parker-Pearson needle. The synovium (Fig. 1) revealed lining cell hyperplasia and a mixed mononuclear and polymorphonuclear cell infiltrate.

Swelling in the right knee persisted despite 3 weeks of oxacillin therapy. Acetylsalicylic acid was then started in a dose of $\frac{2}{3}$ grain/lb/day. During 6 months of this therapy, there was a gradual disappearance of the synovitis. He was observed for another 2 months without therapy and joint symptoms did not return. He has been subsequently lost to further follow-up.

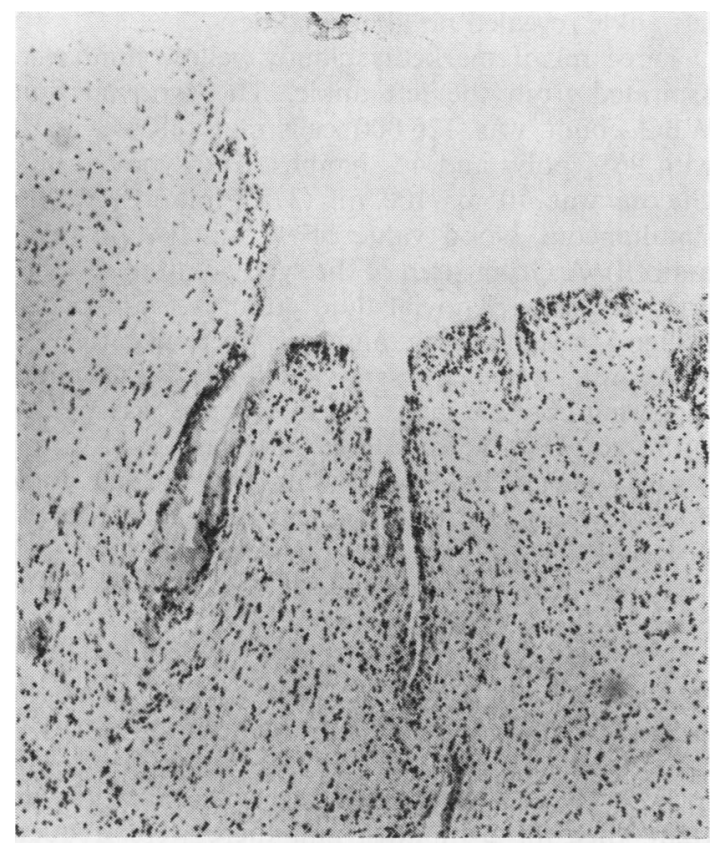

Fig. 1 Synovium (case 1) revealing hyperplasia of synovial lining cells and infiltration with mononuclear and polymorphonuclear cells. $(\times 100)$

C A S E 2

An 11-year-old white male was hospitalised at CGMH after 1 week of pain and swelling in the right knee. There was no recent history of chills, fever, or trauma. The past history was unremarkable.

Physical examination revealed a temperature of $98.6^{\circ} \mathrm{F}\left(37^{\circ} \mathrm{C}\right)$, pulse of $68 / \mathrm{min}$, and blood pressure of $120 / 80 \mathrm{mmHg}(16 \cdot 0 / 10.6 \mathrm{kPa})$. The right knee had 2 plus swelling, 1 plus heat, 1 plus tenderness, and mild limitation of flexion. There were no other joint abnormalities. The remainder of the physical examination was negative except for moderate obesity. A slit-lamp ophthalmological examination was negative.

Laboratory evaluation disclosed the following values haemoglobin of $14 \mathrm{~g} / 100 \mathrm{ml}(\mathrm{g} / \mathrm{dl})$, a haematocrit of $40 \%$, and a WBC count of 7900 cells $/ \mathrm{mm}^{3}$ $\left(7.9 \times 10^{9} / 1\right)$ with $1 \%$ stabs, 77 polys, and $22 \%$ lymphs. The ESR was $9 \mathrm{~mm} / \mathrm{h}$. RF was not present and FANA was negative. Antistreptolysin-O titre (ASO) was 625 Todd units. Urinalysis was negative.

Twelve $\mathrm{ml}$ of cloudy yellow fluid were aspirated from the right knee. The synovial fluid WBC count was 87120 cells $/ \mathrm{mm}^{3}\left(87.12 \times 10^{9} / 1\right)$ with $90 \%$ polys and $10 \%$ lymphs. Synovial fluid cultures for pyogenic bacteria, fungi, and mycobacteria were negative. Blood and throat cultures were also negative. Gram stain of the synovial fluid revealed no organisms.

He was treated with oxacillin, $150 / \mathrm{mg} / \mathrm{kg} /$ day, administered intravenously, for 2 weeks. The pain and swelling in the right knee did not improve with this treatment. Antibiotic therapy was discontinued and he was then started on aspirin, $\frac{2}{3}$ grain/lb/day. Dramatic improvement was noted after 3 days of aspirin therapy. After 1 week of the latter treatment, the knee pain and swelling had completely subsided. In the ensuing year he has continued to have pain, but no swelling. The other knee has also developed pain, but no swelling in the past year.

C A S E 3

An 18-month-old white male was hospitalised at CGMH after a 2-week history of continuous swelling in his right knee. Fever ranging from $100^{\circ}-103^{\circ} \mathrm{F}$ $\left(37 \cdot 6-39 \cdot 4^{\circ} \mathrm{C}\right)$ was noted beginning 4 days before admission. He was also extremely irritable during this period. He had previously been a well baby.

Physical examination revealed a child with normal growth and development. The rectal temperature was $103^{\circ} \mathrm{F}\left(39.4^{\circ} \mathrm{C}\right)$. The right knee was moderately swollen and markedly tender; a small effusion was present. Flexion of the right knee was severely limited. The remainder of the physical examination, including a slit-lamp eye examination, was normal.

Laboratory evaluation revealed the following values: haemaglobin of $11 \mathrm{~g} / 100 \mathrm{ml}(\mathrm{g} / \mathrm{dl})$, a haematocrit of $36 \%$, and a WBC count of 10900 cells $/ \mathrm{mm}^{3}$ $\left(10.9 \times 10^{9} / 1\right)$ with a normal differential. The ESR was $32 \mathrm{~mm} / \mathrm{h}$. RF and FANA were not present. Radiology of the right knee was normal. 
Aspiration of the right knee yielded $5 \mathrm{ml}$ of cloudy yellow fluid. The synovial fluid WBC count was 88000 cells $/ \mathrm{mm}^{3}\left(88 \times 10^{9} / \mathrm{l}\right)$ with $79 \%$ polys and $21 \%$ lymphs. Synovial fluid glucose was $150 \mathrm{mg} / 100$ $\mathrm{ml}(8.33 \mathrm{mmol} / \mathrm{l})$ with a simultaneous blood level of $200 \mathrm{mg} / 100 \mathrm{ml}(11 \cdot 10 \mathrm{mmol} / \mathrm{l})$. The sugar determinations were obtained while the patient was on intravenous glucose therapy.

No organisms were seen on Gram stain of the synovial fluid. Cultures of the synovial fluid for pyogenic bacteria, fungi, and mycobacteria were negative.

He was treated with oxacillin, $100 \mathrm{mg} / \mathrm{kg} / \mathrm{day}$. On the 20th hospital day, an open synovial biopsy was performed on the right knee because of persistent synovitis. Histological examination revealed synovial cell hyperplasia and mononulcear cell infiltration in the underlying connective tissue (Fig. 2).

Antibiotics were discontinued following the biopsy and the child was treated with aspirin, $\frac{2}{3}$ grain/lb/day. After 2 months of aspirin therapy, the swelling in the right knee subsided. Six months later he again developed pain and swelling in the right knee with the swelling persisting during a further 3 months of observation in spite of salicylate therapy. Synovial fluid could not be obtained during this latest flare-up.

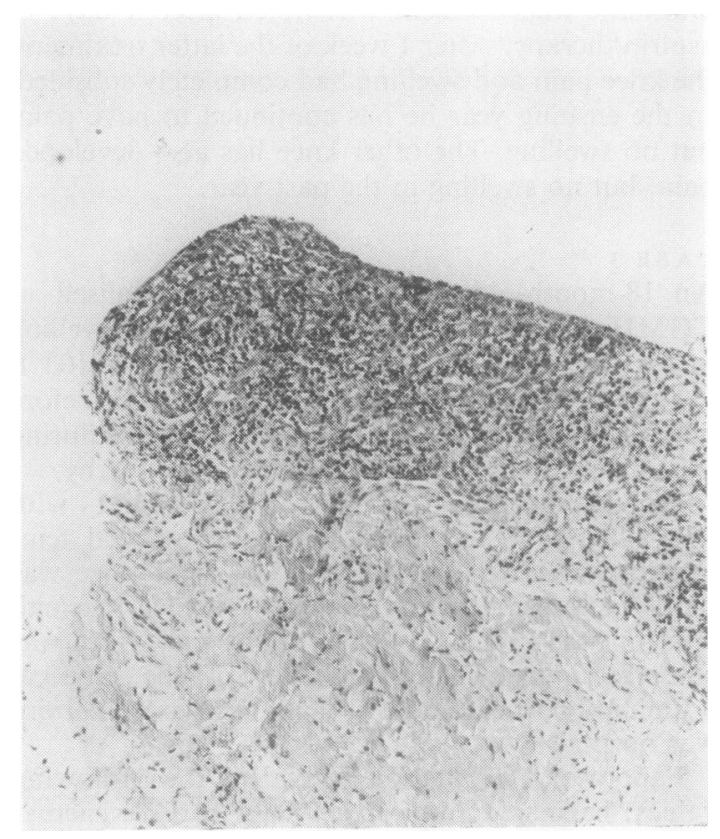

Fig. 2 Synovium (case 3) revealing lining cell hyperplasia and infiltration with mononuclear cells. $(\times 100)$
C A S E 4

A 12-year-old white male noted pain and swelling in his left ankle 10 days after minor trauma. These symptoms continued for 2 days before he was듣 admitted to CGMH. He denied chills or fever. The $\overline{\bar{\sigma}}$ past history was negative except for asthma.

Physical examination revealed a temperature of $\stackrel{\mathbb{\Phi}}{\varrho}$ $100 \cdot 6^{\circ} \mathrm{F}\left(38 \cdot 5^{\circ} \mathrm{C}\right)$, a pulse of $72 / \mathrm{min}$ and a blood pressure of $120 / 80 \mathrm{mmHg}(16 \cdot 0 / 10 \cdot 6 \mathrm{kPa})$. The $\overrightarrow{0}$ general examination, including a slit-lamp ophthalmological examination, was unremarkable. The $\vec{\omega}$ joint examination revealed 2 plus swelling, 2 plus heat, and 2 plus tenderness of the left ankle. Range of motion in the left ankle was normal. There was no other joint involvement.

Laboratory examination disclosed the following values: haemoglobin of $12.5 \mathrm{~g} / 100 \mathrm{ml}(\mathrm{g} / \mathrm{dl}),+$ haematocrit of $37 \%$, and a WBC count of 11000 윽 cells $/ \mathrm{mm}^{3}\left(11 \times 10^{9} / 1\right)$ with $58 \%$ polys, $23 \%$ lymphs, and $14 \%$ eos. The ESR was $40 \mathrm{~mm} / \mathrm{h}$ (Westergren). RF tested by latex fixation was not present. FANA was negative. An ECG was normal and $x$-rays of the left ankle revealed no abnormalities.

Three $\mathrm{ml}$ of markedly cloudy yellow fluid were aspirated from the left ankle. The synovial fluid WBC count was 126000 cells $/ \mathrm{mm}^{3}\left(126 \times 10^{9} / 1\right)$ O with $96 \%$ polys and $4 \%$ lymphs. The synovial fluid glucose was $70 \mathrm{mg} / 100 \mathrm{ml}(3.89 \mathrm{mmol} / \mathrm{l})$ with a simultaneous blood value of $90 \mathrm{mg} / 100 \mathrm{ml}(5.00$ 응 $\mathrm{mmol} / \mathrm{l})$. A Gram stain of the synovial fluid revealed $\stackrel{\mathbb{2}}{2}$ no organisms. Synovial fluid cultures for pyogenic $\overrightarrow{\bar{O}}$ bacteria, mycobacteria, and fungi were negative.

Because the high synovial fluid WBC count suggested possible infection, the patient was treated? with oxacillin, administered intravenously, for a 2 week period. Pain and swelling of the left ankle gradually subsided while on this treatment. He was 3 observed for another 8 months during which time there was no recurrence of arthritis. He was subse- $\frac{\text { 의 }}{3}$ quently lost to further follow-up.

CASE 5

A 9-year-old white female had an 8-month history of intermittent pain and swelling in the left ankle and in both knees. Swelling had been continuous in the right knee for 2 months, and there were frequent? temperature elevations. The rest of the history was $\omega$ unremarkable.

The general physical examination, including a slit-lamp ophthalmological examination, was negative. Minimal swelling without tenderness was present in the left elbow. Both knees were moderately swollen, but not tender to palpation, a $10^{\circ}$ flexion $\vec{D}$ contracture was present in each knee. There was? also moderate swelling without tenderness in the lefto ankle. 
Laboratory examination revealed: haemoglobin of $9.5 \mathrm{~g} / 100 \mathrm{ml}(\mathrm{g} / \mathrm{dl})$, haematocrit of $33 \%$ and a WBC count of 5800 cells $/ \mathrm{mm}^{3}\left(5.8 \times 10^{9} / \mathrm{l}\right)$ with a normal differential. The ESR was $64 \mathrm{~mm} / \mathrm{h}$. Urinalaysis was negative. RF by latex fixation was also negative.

She was initially treated with salicylates administered to tolerance. Fifteen $\mathrm{mg}$ triamcinolone acetonide was injected into each knee. Gold salt treatment was instituted because of continuing synovitis. After 4 months of gold salt therapy, there was moderate improvement in pain and swelling of both knees and the left ankle.

She then suffered a severe flare-up, most marked in the knees. Physical examination revealed moderate swelling, tenderness, and fluid in both knees. Laboratory examination revealed haemoglobin 9.5 $\mathrm{g} / 100 \mathrm{ml}(\mathrm{g} / \mathrm{dl})$ and a WBC count of 7000 cells $/ \mathrm{mm}^{3}$ $\left(7 \times 10^{9} / \mathrm{l}\right)$. The ESR was $112 \mathrm{~mm} / \mathrm{h}$. Six $\mathrm{ml}$ of very cloudy serosanguinous fluid were aspirated from the right knee. The synovial fluid WBC count was 152800 cells $/ \mathrm{mm}^{3}\left(152.8 \times 10^{9} / \mathrm{l}\right)$ with over $90 \%$ polys. The synovial fluid sugar was $56 \mathrm{mg} / 100 \mathrm{ml}$ $(3.11 \mathrm{mmol} / \mathrm{l})$. Three days later both knees were aspirated. The synovial fluid WBC count was 78000 cells $/ \mathrm{mm}^{3}\left(78 \times 10^{9} / \mathrm{l}\right)$ in the right knee and 80000 cells $/ \mathrm{mm}^{3}\left(80 \times 10^{9} / \mathrm{l}\right)$ in the left knee;

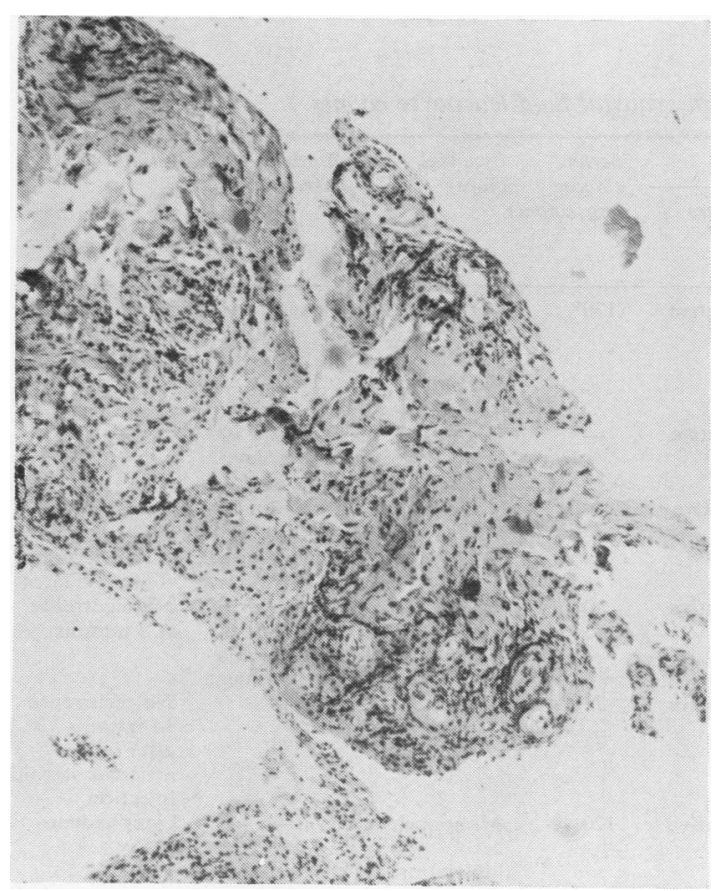

Fig. 3 Synovium (case Ђ) showing mononuclear cell infiltration. $(\times 100)$ synovial fluid sugars were 73 and $85 \mathrm{mg} / 100 \mathrm{ml}$ (4.05 and $4.72 \mathrm{mmol} / \mathrm{l})$ respectively. A simultaneous blood sugar was $81 \mathrm{mg} / 100 \mathrm{ml}(4.50 \mathrm{mmol} / \mathrm{l})$. Gram stain and cultures of the initial synovial fluid were negative.

Triamcinolone acetonide was injected into each knee; this treatment resulted in a marked decrease of pain and swelling. The patient has subsequently been observed for 14 months and there has been no recurrence of the severe pain, swelling, or effusion in the knees.

\section{A S E 6}

A 14-year-old black female was admitted to CGMH with a 2-day history of fever as high as $104^{\circ} \mathrm{F}\left(40^{\circ} \mathrm{C}\right)$ associated with pain and swelling of both elbows, knees, and right ankle. She had no rash or sore throat. There was no previous history of joint pain or swelling.

Physical examination revealed that the patient had a temperature of $104^{\circ} \mathrm{F}\left(40^{\circ} \mathrm{C}\right)$, pulse $110 / \mathrm{min}$, and blood pressure of $120 / 80 \mathrm{mmHg}(16 \cdot 0 / 10 \cdot 6$ $\mathrm{kPa})$. She was a thin girl who appeared toxic on admission. The general examination, including a slit-lamp ophthalmological examination was negative except for the joints.

The right elbow was hot, moderately swollen, and extremely tender. There was also moderate swelling and tenderness of the left elbow. Flexion of both elbows was limited about $20^{\circ}$, and was associated with severe pain. There was minimal swelling and tenderness of the right knee. The remainder of the joint examination was normal.

Laboratory evaluation revealed the following values: haemoglobin $11 \mathrm{~g} / 100 \mathrm{ml}(\mathrm{g} / \mathrm{dl})$, haematocrit $34 \%$, and $\mathrm{WBC}$ of 26000 cells $/ \mathrm{mm}^{3}\left(26 \times 10^{9} / \mathrm{l}\right)$ with $1 \%$ stabs, $86 \%$ segs, and $13 \%$ lymphs. RF and FANA were negative. LE cells were not present. ESR was $28 \mathrm{~mm} / \mathrm{h}$. ASO titre was 166 Todd units. An ECG revealed a sinus tachycardia. Radiology of both elbows and knees was normal.

Five ml of markedly cloudy yellow fluid were aspirated from the right elbow. The synovial fluid WBC count was 95480 cells $/ \mathrm{mm}^{3}\left(95.48 \times 10^{9} / 1\right)$ with $94 \%$ polys and $6 \%$ lymphs. The synovial fluid glucose was $116 \mathrm{mg} / 100 \mathrm{ml}(6.44 \mathrm{mmol} / \mathrm{l})$ with a simultaneous blood glucose of $120 \mathrm{mg} / 100 \mathrm{ml}$ $(6.66 \mathrm{mmol} / \mathrm{l})$. Blood and synovial fluid cultures were negative for bacteria and fungi. No organisms were seen on Gram stain of the synovial fluid.

During the first 4 days of hospitalisation the other knee and both wrists and ankles developed swelling and tenderness. Throughout her hospital stay the patient had daily temperature peaks as high as $104^{\circ} \mathrm{F}\left(40^{\circ} \mathrm{C}\right)$. No rashes were observed.

Juvenile rheumatoid arthritis (JRA) was diagnosed. 
She was treated with acetylsalicylic acid, 1 grain/lb/ day which partially improved the polyarthritis, but did not control the fever.

One month after the onset of arthritis she developed massive generalised lymphadenopathy. Physical examination revealed enlarged lymph nodes in the anterior and posterior cervical chains, both axillae and both inguinal regions. The nodes ranged in size from $0.5 \mathrm{~cm}$ in diameter. The liver and spleen were also enlarged. Both knees had moderate pain and swelling. A lymphoma was considered a diagnostic possibility and she was readmitted to CGMH.

The haemoglobin was now $9.6 \mathrm{~g} / 100 \mathrm{ml}(\mathrm{g} / \mathrm{dl})$, haematocrit $29 \%$, and the WBC count 28000 cells $/ \mathrm{mm}^{3}\left(28 \times 10^{9} / \mathrm{l}\right)$ with $6 \%$ stabs, $80 \%$ polys, and $14 \%$ lymphs. Bone marrow examination was normal. A lymph node biopsy was initially considered consistent with a lymphocytic lymphoma and she was therefore treated with prednisone $2.5 \mathrm{mg} / \mathrm{kg} / \mathrm{day}$ and vincristine $1.5 \mathrm{mg} / \mathrm{m}^{2}$ weekly. After 2 months of this therapy the lymphadenopathy and joint symptoms abated. Biopsy of the right knee showed mononuclear cell infiltration (Fig. 3).

Consulting pathologists subsequently examined the lymph node biopsy and agreed that the lymph node findings were those of follicular hyperplasia consistent with JRA. They felt there was no evidence for the diagnosis of lymphoma. The prednisone and vincristine were therefore discontinued, and there has been no further recurrence of arthritis or lymphadenopathy in the ensuing 8 months of observation.

\section{Discussion}

Very high synovial fluid leucocyte counts have been described only infrequently in patients without infectious arthritis. Ropes and Bauer (1953) examined synovial fluids from 1500 patients with various arthritides and, excluding their patients with septic arthritis, found synovial fluid leucocyte counts greater than 80000 cells $/ \mathrm{mm}^{3}\left(80 \times 10^{9} / \mathrm{l}\right)$ in only one case each of rheumatoid arthritis and rheumatic fever. Frischknecht and Steigerweld (1975) recently reported 5 patients with pseudogout with synovial fluid leucocyte counts between 65000 and 100000 cells $/ \mathrm{mm}^{3}\left(65-100 \times 10^{9} / 1\right)$. The 6 patients described in this report had cynovial fluid leucocyte counts varying from 87000 to 126000 cells $/ \mathrm{mm}^{3}$ (87-126 $\left.\times 10^{9} / 1\right)$.

Cases 1 to 4 presented with monoarticular arthritis, 3 involving the knee and 1 the ankle. Three of the 4 also had fever. Septic arthritis was assumed to be the initial diagnosis because of the very high synovial fluid WBC counts. In all 4 cases, however, examination of synovial fluids for organisms by smear and

Table 1 Clinical and laboratory findings in 6 children with high synovial fluid leucocyte counts

\begin{tabular}{|c|c|c|c|c|c|c|c|c|c|c|c|}
\hline \multirow[t]{2}{*}{ Case } & \multirow{2}{*}{$\begin{array}{l}\text { Age } \\
\text { (years) }\end{array}$} & \multirow{2}{*}{$\begin{array}{l}E S R \\
(m m / h)\end{array}$} & \multirow{2}{*}{$\begin{array}{l}\text { Affected } \\
\text { joints }\end{array}$} & \multicolumn{4}{|c|}{ Synovial fluid } & \multirow{2}{*}{$\begin{array}{l}\text { Serum } \\
\text { glucose } \\
(\mathrm{mg} / 100 \mathrm{ml})\end{array}$} & \multirow{2}{*}{$\begin{array}{l}\text { Synovial } \\
\text { biopsy } \\
\text { l) }\end{array}$} & \multirow{2}{*}{$\begin{array}{l}\text { Antibiotic } \\
\text { therapy }\end{array}$} & \multirow[t]{2}{*}{ Comments } \\
\hline & & & & $\begin{array}{l}\text { WBC } \\
(\text { cells/ } \\
\left.\mathrm{mm}^{3}\right)\end{array}$ & $\begin{array}{l}\text { Polys } \\
(\%)\end{array}$ & $\begin{array}{l}\text { Glucose } \\
(\mathrm{mg} / \\
100 \mathrm{ml})\end{array}$ & Culture & & & & \\
\hline 1 & $3 \frac{1}{2}$ & 36 & Knee & 93000 & 96 & 62 & Negative & $170^{*}$ & $\begin{array}{l}\text { Mononuclear } \\
\text { and polymor- } \\
\text { phonuclear } \\
\text { cell infil- } \\
\text { tration }\end{array}$ & $\begin{array}{l}\text { Oxacillin } 100 \\
\mathrm{mg} / \mathrm{kg} / \mathrm{day} \\
\text { no response }\end{array}$ & $\begin{array}{l}\text { Synovitis } \\
\text { persisted } 6 \\
\text { months }\end{array}$ \\
\hline 2 & 11 & 9 & Knee & 87120 & 90 & 37 & Negative & - & - & $\begin{array}{l}\text { Oxacillin } 100 \\
\mathrm{mg} / \mathbf{k g} / \mathrm{day}, \\
\text { no response }\end{array}$ & 一 \\
\hline 3 & $1 \frac{1}{2}$ & 32 & Knee & 88000 & 79 & 150 & Negative & $200 *$ & $\begin{array}{l}\text { Mononuclear } \\
\text { cell } \\
\text { infiltration }\end{array}$ & $\begin{array}{l}\text { Oxacillin } 100 \\
\mathrm{mg} / \mathrm{kg} / \mathrm{day}, \\
\text { no response }\end{array}$ & $\begin{array}{l}\text { Recurrence of } \\
\text { synovitis in } \\
\text { the right knee } \\
6 \text { months later }\end{array}$ \\
\hline 4 & 12 & 40 & Ankle & 126000 & 90 & 70 & Negative & 90 & - & $\begin{array}{l}\text { Oxacillin } 100 \\
\text { mg/kg/day, } \\
\text { questionable } \\
\text { improvement }\end{array}$ & $\begin{array}{l}\text { No recurrence } \\
\text { at } 8 \text { months }\end{array}$ \\
\hline 5 & 9 & 112 & $\begin{array}{l}\text { Polyarth- } \\
\text { ritis }\end{array}$ & 150000 & 90 & 56 & Negative & 73 & - & - & $\begin{array}{l}\text { No recurrence } \\
14 \text { months } \\
\text { after intra- } \\
\text { articular steroid } \\
\text { injection }\end{array}$ \\
\hline 6 & 14 & 28 & $\begin{array}{l}\text { Polyarth- } \\
\text { ritis }\end{array}$ & 95000 & 94 & 116 & Negative & 120 & $\begin{array}{l}\text { Mononuclear } \\
\text { cell } \\
\text { infiltration }\end{array}$ & - & $\begin{array}{l}\text { Lymphadeno- } \\
\text { pathy }\end{array}$ \\
\hline
\end{tabular}

*Obtained while patient was receiving intravenous glucose.

Conversion: traditional to SI units: WBC -1000 cells $/ \mathrm{mm}^{3}=1 \times 109 / 1$.

Glucose and serum glucose $-1 \mathrm{mg} / 100 \mathrm{ml}=0.0555 \mathrm{mmol} / 1$. 
culture proved negative. Only 1 patient (case 1) had previous antibiotic therapy which could have inhibited bacterial growth. After synovial fluid leucocyte counts were obtained, antibiotics were administered to all 4 patients without dramatic improvement in the joints, although case 4 showed a gradual subsidence of synovitis over 2 weeks. The negative smears and cultures and the generally poor response to antibiotics would seem to rule out infectious arthritis. The histories in cases 1 and 3 are more consistent with the diagnosis of JRA. Case 1 had synovitis lasting 6 months and case 3 had a recurrence of pain and swelling in the same knee 6 months after the initial episode. The aetiology of the joint symptoms in cases 2 and 4 remains unclear. In both instances, the synovitis was of short duration. One child (case 2) has had joint pain in both knees 1 year after the initial onset of arthritis, suggesting a polyarthritis of non-infectious aetiology.

Two of these 4 children with monoarticular disease underwent synovial biopsy of the involved knee. One synovium (case 3 ) revealed mononuclear cell infiltration consistent with the diagnosis of JRA. The other synovial biopsy (case 1) revealed infiltration with both mononuclear and polymorphonuclear cells; this synovium was obtained within 2 weeks of the onset of symptoms. Although polymorphonuclear leucocyte infiltration of the synovium is found in infectious arthritis, it was also found in the early stages of JRA by Schumacher and Kitridon (1972). Thus, the synovial tissue histology in these 2 cases was compatible with the diagnosis of JRA, although not pathognomonic.

Cases 5 and 6 had polyarthritis. Case 5 had JRA for 8 months, and during an acute exacerbation of pain and swelling of both knees the synovial fluid WBC count in the right knee was approximately 150000 cells $/ \mathrm{mm}^{3}\left(150 \times 10^{9} / \mathrm{l}\right)$. Examination of synovial fluid for infection by smear and culture was negative. The symptoms abated after each knee was injected with triamcinolone acetonide. Subsequent follow-up during the next 14 months revealed no further acute flare-ups. The possibility of infection superimposed on joints previously involved with JRA was considered, but the failure to find organisms and the prolonged remission contradicted this possibility.

Case 6 had daily fever peaks accompanying her arthritis as the major manifestation of her disease, and later developed lymphadenopathy. A lymph node biopsy showed follicular hyperplasia, compatible with the diagnosis of JRA (Motulsky et al., 1952). The polyarthritis, fever, and lymphadenopathy were not secondary to a tumour of the lymphoproliferative system (Spilberg and Meyer, 1972; Emkey et al., 1973) as initially presumed. JRA seemed the most likely diagnosis.

The findings suggest that these 6 children did not have infectious arthritis despite synovial fluid leucocyte counts greater than 80000 cells $/ \mathrm{mm}^{3}$ $\left(80 \times 10^{9} / 1\right)$. The clinical picture in all is compatible with the diagnosis of JRA. Children 2, 4, and 5 met the American Rheumatism Association criteria for JRA (Brewer et al., 1972). However, a definite diagnosis of JRA cannot be made in the remaining patients. Other aetiologies have been considered in these patients, such as, a virus infection or toxic agents. There is, however, no history for the latter possibility, and such high synovial leucocyte counts would be unusual for a viral induced arthritis.

The typical synovial fluid leucocyte count in JRA (Hollander and McCarthy, 1972; Calabro, 1974) is reported to be similar to that of adult rheumatoid arthritis. These cases indicate, however, that the leucocyte count in JRA may be quite high, at times in the range usually considered consistent with infectious arthritis.

\section{References}

Brewer, E. J., Bass, J. C., Cassidy, J. T., et al., (1972). Criteria for the classification of juvenile rheumatoid arthritis. Bulletin on the Rheumatic Diseases, 23, 712-719.

Calabro, J. J. (1974). The three faces of juvenile rheumatoid arthritis. Hospital Practice, 9, 61-68.

Emkey, R. D., Ragsdale, B. D., Ropes, M. W. et al. (1973). A case of lymphoproliferative disease presenting as juvenile rheumatoid arthritis: Diagnosis by synovial fluid examination. American Journal of Medicine, 54, 825-828.

Frischknecht, J., and Steigerwald, J. C. (1975). High synovial white blood cell counts in pseudogout. Archives of Internal Medicine, 135, 298-299.

Hollander, J. L., and McCarthy, D. J. (1972). Arthritis and Allied Conditions, 8th ed., p. 74. Ed. by J. L. Hollander. Lea and Febiger: Philadelphia.

Motulsky, A. C., Weinberg, S., et al. (1952). Lymph nodes in rheumatoid arthritis. Archives of Internal Medicine, 90, 660-676.

Ropes, M. W., and Bauer, W. (1953). Synovial Fluid Changes in Joint Disease, p. 23. Harvard University Press: Cambridge, Mass.

Schumacher, H. R., and Kitridou, R. C. (1972). Synovitis of recent onset. Arthritis and Rheumatism, 15, 465-485.

Spilberg, I., and Meyer, G. J. (1972). The arthritis of leukemia Arthritis and Rheumatism, 15, 630-635. 